\title{
Future of Social Media Marketing in tier III cities of Maharashtra
}

\author{
Kandekar Tanmay \\ Associate Prof, NIFT Mumbai \\ tskandekar@gmail.com
}

\begin{abstract}
With rise of technology and disposable income consumers from smaller cities are also showing tendency to buy fashion and lifestyle products. Especially the young consumers, who are more tech-savvy and trend follower would be looking for the experience of having a fashionable product. As the products are not available in the small city market, they visit the nearest big city market or try to go online to purchase product. The advertisements on social media help them to know the latest offerings in the market, hence they look forward to such promotions. The brand marketer needs to make sure that the advertisement on social media should be a proper combination of factors like pricing, discounts, quality, celebrity endorsements and language along with cultural \& religious consideration.
\end{abstract}

Index Terms-Social Media Marketing, SM promotions, Tier III, Fashion and Lifestyle.

\section{INTRODUCTION}

$\mathrm{T}$ HE growth in the retail sector in India is very much evident from last few years. As per the IBEF report in March 2019, the retail market size is estimated to grow by $60 \%$ and expected to reach at US\$ 1.1 Trillion by 2020-21. This growth is led by the increase of domestic retail companies (Big, Bazar, pantaloons, westside etc.) as well as the entry of the international players like (Walmart, Max, H\&M, Zara etc.). The benefits the customers get is the high quality and better variety products. The presence of multinational companies makes the business very competitive and companies strive further to improve the quality of the product as well as the after sales-service. With the country life India, which is culturally and geographically diverse, it would be very challenging for the companies to market their product. The skill of marketer is evaluated with the reach of the concept of the product to the consumers. And in such cases technology plays a crucial role. Most of the brands are very dependent on creating a buzz through social media as it is considered to be the cheapest advertisement medium which has widespread reach than the traditional way of marketing especially for the fashion and lifestyle products.

With the surge in the disposable income of the Indian consumers, and with higher literacy rate, people are more conscious about what they purchase. Apart from the items coming under the daily needs, another category which is showing higher momentum is the lifestyle category. Demand for these products is increasing and it is clear through the growth of the mall culture in the metro and tier I cities. The presence of cheaper smartphones and availability of the Internet makes it easy for the consumers to connect to the brand easily.

In this paper, an effort is made to study whether the social media advertisement makes any impact on the consumers of tier III cities of Maharashtra. A survey is conducted to check the awareness about the fashion and lifestyle products and to find out the factors which impacts their buying behaviour. This study will be helpful for the marketer to create an advertisement campaign on social media for the tier III cities of Maharashtra.

\section{OBJECTIVE}

The objectives of the research are focused on the consumer responses from the tier III cities of the Maharashtra state.

- To study the fashion consciousness of customers

- To study the awareness of consumers about the social media advertisement.

- To find out whether social media advertisement makes an impact on the purchase behaviour of the consumers of tier III cities.

\section{REVIEW OF LITERATURE}

The various initiatives by the government in recent past makes the Indian retail sector showing a steep upward curve. For example, the allowing of FDI in retail and the uniform tax structure (GST) making it easier for the companies to do business. During last 4-5 years, there is lot of positivity in the Indian business scenario. India's rank in Ease of Doing Business was hovering around 130 among of 190 nations till 2016. But after the strong steps taken by government, it rose to 100 in 2017 and in 2018 it was 77. The result is there is a growth of the organized retail sector from $9 \%$ to $12 \%$ with in the span of last 3 years. It is expected that the organised retail sector will reach to 18 $\%$ of the total retail, while the e-commerce will occupy 8 $\%$ as compared to $74 \%$ of unorganised sector till 2021 , which is the significant improvement by organised sector. The World Economic Forum report 2019, states with respect to Indian economy that

- $60 \%$ of the domestic consumption leads to higher production possibilities

- $22 \%$ of the income is saved in various instruments, which is very good indicator 
- $\quad$ Working population is very young (median age of 28 years)

- Simplicity in tax filing and allowance of FDI in single brand retail

- Make in India campaign to give boost to local production

- Improvement in the infrastructure facilities (better rails and roads, smart cities, industrial corridors etc.)

- Simplified business approvals improving the ease of doing business

Indian consumers are more aware about the gamut of product variety and he has become more experimental in the selection. Gone are the days where only one product in a category is available but now, the range has products offering are increased manifolds. All this information is available to consumer with a click of a button, be it in a metro city or tier II and tier III cities. The presence of smartphone and the high-speed internet made it possible to connect the small city consumer with the new arrivals in the market. As per report published in statista.com, there will be more than 760 million smartphone users in India by 2021 (Asher 2020). With young population is more literate and they have risk appetite, they try to buy online.

Fashion \& lifestyle is the most sought-after product in the online commerce. The category contents fashion garments, jewellery, wrist watches, sportswear, luxury bags and belts and sunglasses. In the world of fast fashion, a study conducted by The State of Fashion (2019) revealed that almost 1 in every seven persons does not want to be photographed in the same garment again and more than $30 \%$ consider it old after wearing two or three times.

The new age marketing has a little edge over the traditional one in the era of technology. One such tool, that most of the marketers are using is the social media marketing. It involves the promoting the product on Facebook, Instagram, Pinterest, Twitter etc. it helps consumers to get all details and they can purchase it online through various e-com platforms like Flipkart, Jabong, Amazon etc. These companies are claiming that the business from such smaller towns has reached to almost $50 \%$ of their total sales.

As per the India Internet report (2019), there are more than 450 million, which is increased to 700 million (Statista, 2020) users of internet and those are existing in both rural and urban parts of India. The entertainment sites are surfed by more than $52 \%$ of tier II and tier III cities users and the number of social media user are 326 million (Keelery, 2020).

\section{RESEARCH METHODOLOGY}

In order to study the impact of social media marketing in tier III cities a questionnaire survey was done. The objective of the survey to find out the fashion consciousness, availability of lifestyle products and how they perceive the social media advertisements and their online purchase behaviour. The area of study was selected as Maharashtra state only. The sampling technique was convenient and survey was conducted in 2019 . The sample size came out to be 570 .

\section{FINDINGS AND DATA ANALYSIS}

Out of the 570 respondents, $44.2 \%$ were females and $55.8 \%$ were male. A total of 87 cities of Maharashtra state have participated in the survey.

The findings of the survey are as follows:

With respect to the fashion consciousness, $70.5 \%(75.5 \%$ of males and $64.3 \%$ of females) of respondents said they are fashion conscious. The availability of the fashion and lifestyle products is quite critical for the business, hence upon asking them about the availability of the products, most of the respondents said that the product is not available in bulk in their nearby market.

TABLE 1: AVAILABILITY PERCEPTION OF FASHION \& LIFESTYLE PRODUCTS

\begin{tabular}{|l|l|l|}
\hline $\begin{array}{l}\mathrm{Sr} \\
\text { no }\end{array}$ & Items & $\begin{array}{l}\% \\
\text { respondents }\end{array}$ \\
\hline 1 & Fashion garments & $48 \%$ \\
\hline 2 & Branded watches & $37.9 \%$ \\
\hline 3 & $\begin{array}{l}\text { Branded leather bags and } \\
\text { belts }\end{array}$ & $44.9 \%$ \\
\hline 4 & Branded Shoes & $40.3 \%$ \\
\hline 5 & Branded Jewellery & $35.1 \%$ \\
\hline 6 & Branded Sunglasses & $44.6 \%$ \\
\hline
\end{tabular}

As the products are not available widely, $73.5 \%$ of the respondents are purchasing it online through various ecommerce websites, out of which $48.1 \%$ people are satisfied with the purchase and only $36.8 \%$ will do the repeat purchase. The reason for non-satisfaction mentioned by respondents are size and price mismatch, occurrences of fake/defective products, deceptive claims, not comfortable with online payment system, return policy, and privacy issue.

TABLE 2: RESPONSES TOWARDS THE SOCIAL MEDIA PROMOTIONS

\begin{tabular}{|l|l|l|}
\hline $\begin{array}{l}\text { Sr } \\
\text { no }\end{array}$ & Parameters & $\begin{array}{l}\% \\
\text { respondents }\end{array}$ \\
\hline 1 & $\begin{array}{l}\text { Awareness about the SM } \\
\text { advertisement }\end{array}$ & $74.7 \%$ \\
\hline 2 & $\begin{array}{l}\text { Inclinations towards SM } \\
\text { advertisement }\end{array}$ & $56.2 \%$ \\
\hline 3 & Like to go through it & $55.4 \%$ \\
\hline 4 & Click on the link & $50.2 \%$ \\
\hline 5 & Get influenced by it & $36.1 \%$ \\
\hline 6 & Trust the claim & $31.6 \%$ \\
\hline 7 & $\begin{array}{l}\text { Buy it online after the } \\
\text { market survey }\end{array}$ & $41.4 \%$ \\
\hline
\end{tabular}


The perception of the respondents with respect to the social media is studied on following points:

- Awareness about the promotion done on social media (SM)

- The impact it creates among the users

The table clearly indicates that the people are aware about the social media advertisements $(74.7 \%)$, but only $41.4 \%$ actually buy the products online, this means that there is a huge scope for the brand marketers to do better advertising. The lower level of trust indicates that the with respect to tier III city consumers, the advertisement has to be more realistic and the factors responsible for the purchase should be focused on. The 7 factors responsible for the consumer buying are studies for tier III city. The lower number indicates the higher preferences.

TABLE 3: RANKING OF FACTORS BY RESPONDENTS

\begin{tabular}{|l|l|l|}
\hline Rank & Factors & Mean \\
\hline 1 & Price & 2.11 \\
\hline 2 & Quality & 2.28 \\
\hline 3 & Guaranty/Warranty & 3.77 \\
\hline 4 & Discounts & 4.05 \\
\hline 5 & Brand name & 4.37 \\
\hline 6 & Proximity of Store & 5.52 \\
\hline 7 & Celebrity Endorsement & 5.91 \\
\hline
\end{tabular}

From the table it is evident that, price plays very important role in purchase of products. This indicates that the tier III market is very price sensitive. The lower rank of celebrity endorsement indicates that, even though customers like to watch the promotional advertisement which involves celebrities, but they purchase a product with lower price points.

\section{CONCLUSION \& Future SCOPE}

Not only the customer from big metro cities but people from smaller cities are also aware about the new brands and their features, thanks to the technology and social me- dia. More and more young consumers are using social media for various of purposes, be it a photo or message shearing, browsing/surfing or trying to learn new things. Brands should use social media to connect to consumers by understanding their aspirational needs. The social media marketing with appropriate price points, product/size variation, promotion in local language, cultural beliefs, use of local celebrities will definitely help the brand to acquire the higher market share in tier III cities. The perception of the brand managers can be added to these findings for formulating the strategy of the social media promotion. The study from other states to know the perception of consumers in that areas will help to create the nationalwide strategy for the marketers.

\section{LIMITATIONS}

The research is only limited to the tier III cities of Maharashtra. The study is only focused on the fashion and lifestyle products.

\section{REFERENCES:}

[1] Sita M, Tyagi A, Understanding Social Media Mindset of Consumers: An Indian Perspective JISTEM - Journal of Information Systems and Technology Management Vol. 12, No. 2, May/Aug., 2015 pp. 203-218

[2] Suja P Mathews, Sunu George, Growth and Future of Social Media International Journal of Advanced Research in Computer Engineering \& Technology (IJARCET) Volume 2, Issue 12, December 2013 ISSN: $2278-1323$

[3] Keelery S, (2020), Number of internet users in India from 2015 to 2020, Retrieved from https://www.statista.com/statistics/255146/ number-of-internet-users-in-india/

[4] Harvey S (2018), What is a lifestyle brand? When brands become a way of life, Retrieved from http://fabrikbrands.com/why-lifestylebrands-become-a-way-of-life/

[5] McKinsey \& company (2019), The State of Fashion 2019, Retrieved from https://cdn.businessoffashion.com/reports/ The_State_of_Fashion_2019_v3.pdf

[6] Asher V (2020), Smartphone users in India 2015-2025, Retrieved from https://www.statista.com/statistics/467163/forecast-ofsmartphone-users-in-india/

[7] Lifestyle brand (2020), Wikipedia, Retrieved from https://en.m. wikipedia.org/wiki/Lifestyle_brand

[8] Growth of Indian fashion e-commerce (2019), Images: Business of research, Retrieved from https://www.indiaretailing.com/2019/03/ 08 /fashion/growth-of-indian-fashion-e-commerce/

[9] Keelery S, (2020), Number of social network users India 20152023, Retrieved from https://www.statista.com/statistics/278407/ number-of-social-network-users-in-india/ 